\title{
PENGGUNAAN MEDIA PEMBELAJARAN BERBASIS ICT(INFORMATION COMMUNICATIONS TECHNOLOGIES) DALAM MENINGKATKAN MOTIVASI BELAJAR PESERTA DIDIK
}

\author{
Hendra Saputra S. Adiko \\ 1Program Studi PGSD, Universitas Muhammadiyah Gorontalo \\ e-mail: hendra.adikoumg@gmail.com
}

\begin{abstract}
One of the main tasks of an educator in realizing the goals of education in school is to develop learning strategies effectively. In learning activities especially in science learning about the process of the formation of rain requires the efforts of teachers in understanding what approaches are suitable for achieving learning goals. One suitable approach in instilling the concept of the process of rain formation is by using ICT-based media. ICT-based learning is a learning process by utilizing information technology. The purpose of this paper is to show that the use of ICT-based media can improve the learning motivation of Grade III students at the Gorontalo State University Laboratory. The method used to improve students 'motivation through classroom action research is done through evaluating student learning outcomes in which at the initial observation when educators did the learning process not using ICT-based media the results of students' mastery learning were only 9 people out of 23 students who subject to action or 39\%. But after reflection again using ICT-based media, students' learning completeness increased to 21 students who managed to achieve learning completeness or $91 \%$.
\end{abstract}

Keywords: ICT Media; Learning Motivation

\begin{abstract}
Abstrak
Salah satu tugas utama seorang pendidik dalam mewujudkan tujuan-tujuan pendidikan di sekolah adalah mengembangkan strategi pembelajaran secara efektif. Dalam kegiatan pembelajaran khususnya dalam pembelajaran IPA tentang Proses terbentuknya hujan diperlukan upaya guru dalam memahami pendekatan apa yang cocok untuk mencapai tujuan pembelajaran. Salah satu pendekatan yang cocok dalam menanamkan konsep proses terbentuknya hujan adalah dengan penggunaan media berbasis ICT. Pembelajaran berbasis ICT adalah proses pembelajaran dengan memanfatkan teknologi informasi. Tujuan dari makalah ini untuk menunjukan bahwa penggunaan media berbasis ICT dapat meningkatkan Motivasi belajar peserta didik kelas III SD Laboratorium Universitas Negeri Gorontalo. Metode yang digunakan untuk meningkatkan motivasi belajar peserta didik
\end{abstract}


melalui penelitian tindakan kelas yang dilakukan melalui evaluasi hasil belajar pesert didik yang dilakukan dimana pada observasi awal ketika pendidik melakukan proses pembelajaran tidak menggunakan media berbasis ICT hasil ketuntasan belajar peserta didik hanya 9 orang dari 23 peserta didik yang dikenai tindakan atau $39 \%$. Namun setelah dilakukan refleksi kembali dengan menggunakan media berbasisi ICT ketuntasan belajar peserta didik meningkat mencapai 21 peserta didik yang berhasil mencapai ketuntasan belajar atau $91 \%$.

Keywords: Media /CT; Motivasi Belajar

\section{PENDAHULUAN}

Dari beberapa faktor yang membuat peserta didik jenuh atau bosan dan tak bersemangat dalam proses pembelajaran, kepiawaian pengajar sangat menentukan sebagai penyebabnya. Salah satu kepiawaian pengajar yang dituntut adalah pemilihan media pembelajaran yang relevan dengan bahan ajar atau materi pembelajaran.Media pembelajaran adalah sebuah alat yang berfungsi dan digunakan untuk menyampaikan pesan pembelajaran. Sedangkan pembelajaran adalah proses komunikasi antara pembelajar, pengajar, dan bahan ajar. Dapat dikatakan bahwa bentuk komunikasi tidak akan berjalan tanpa bantuan sarana untuk menyampaikan pesan. Bentuk-bentuk stimulus yang dapat dipergunakan sebagai media diantaranya adalah hubungan atau interaksi manusia, realitas, gambar bergerak atau tidak, tulisan dan suara yang direkam. Maka dengan kelima bentuk stimulus ini akan membantu pembelajar mempelajari bahan pelajaran. Atau dapat dikatakan bahwa bentuk-bentuk stimulasi dapat dipergunakan sebagai media pembelajaran adalah suara, lihat, dan gerakan.

Dalam kegiatan pembelajaran IPA pada materi Proses terbentuknya Hujan diperlukan kepiawaianpendidik dalam memahami pendekatan apa yang cocok untuk mencapai tujuan pembelajaran. Salah satu pendekatan yang cocok dalam proses pembelajaran menanamkan konsep proses terbentuknya hujan adalahdenganpenggunaan media berbasis ICT.

Berdasarkan kenyataan bahwa yang ada di lapangan ternyata di SD Laboratorium UNG pelaksanaan proses pembelajaran IPA pada materi proses terbentuknya hujan kelas III belum maksimal dikarenakan guru hanya menggunakan metode convensional sedangkan Peserta Didik 
hanya terus mendengarkan penjelasan guru tentang materi yang diajarkan hal ini menimbulkan ke jenuh dari Peserta Didik untuk menerima pelajaran sehingga berdampak pada rendahnya hasil belajar peserta didik ini sesuaia hasil observasi awal dalam penelitian ini nampak dari 23 peserta didik yang memperoleh nilai 75 keatas hanya 9 orang atau $39 \%$ dari jumlah seluruh Peserta Didik yang dikenai tindakan, sedangkan Peserta Didik yang belum tuntas dalam proses pembelajaran ini masih mendominasi dengan capaian 14 orang peserta didik atau $61 \%$. Sebagai gambaran penyebabnya antara lain: peserta didik tidak termotivasi dalam mengikuti proses pembelajaran yang disajikan oleh guru hal ini nampak sebagian besar peserta didik hanya asik ngobrol dengan teman disampingnya. Apabila hal ini tidak segera di tindaklanjuti maka yang menjadi salah satu tujuan dari kurikulum yaitu memahami proses terbentuknya hujan tidak akan tercapai.

Berdasarkan uraian latar belakang masalah di atas, maka penulis bermaksud untuk melakukan suatu Penelitian Tindakan yang diformulasikan dengan judul Penggunaan Media Pembelajaran berbasis ICT (Information Communications Technologies) Dalam
Meningkatkan Motivasi Belajar Peserta

Didik.Berdasarkan uraian latar belakang, maka masalah dalam penelitian ini dirumuskan "Apakah dengan Penggunaan Media Pembelajaran berbasis ICT (Information Communications Technologies) dapat Meningkatkan Motivasi Belajar Peserta Didik kelas III SD Laboratorium Universitas Negeri Gorontalo dapat meningkat?" dengan tujuan penelitian adalah untuk melihat sejaauh mana penggunaan media pembelajaran berbasis ICT dapat meningkatkan motivasi belajar yang berimbas pada meningkatnya presetsi hasil belajar peserta didik.

State Of The Art penelitian sebelumnya berfungsi untuk analisas dan memperkaya pembahasan penelitian, serta membedakannya dengan penelitian yang sedang dilakukan. Dalam penelitian ini disertakan jurnal penelitian sebelumnya yang berhubungan dengan Penggunaan Media Pembelajaran berbasis ICT (Information Communications Technologies) Dalam Meningkatkan Motivasi Belajar Peserta Didik jurnal tersebut diantaranya adalah: penelitian dengan judul Penggunaan media pembelajaran Berbasis ICT (Information, Communication, and Technology) dan pengaruhnya 
Terhadap tingkat kelulusan Ujian Nasional Siswa Pada sekolah menengah di Kota Palopo di teliti oleh Rosdiana pada tahun 2016 di SMA di kota Palopo yang menceritakan tentang Media pembelajaran berbasis ICT sangat berpengaruh terhadap hasil belajar siswa khususnya nilai dari Ujian Nasional pada 3 (tiga) tahun terakhir) ini. Dari gambaran data yang kami peroleh terlihat nilai rata-rata dari hasil Ujian Nasional Siswa dalam 3 (tiga) tahun terakhir di 5 (lima) sekolah menengah yang berada di kota Palopo dan jenis media pembelajaran yang digunakan oleh para pengajarnya, terlihat bahwa cenderung terjadi perbedaan hasil ujian yang lebih baik bagi siswa yang pengajarnya menggunakan media pembelajaran berbasis ICT dibandingkan dengan pengajar yang tidak menggunakan ICT dalam media pembelajarannya.

\section{METODE PENELITIAN}

Penelitian ini dilaksanakan di SD Laboratorium UNG Kota Gorontalo, Penelitian ini menggunakan metode Penelitian Tindakan. Yang dilaksanakan pada akhir semester 2tahun pelajaran 2017-2018. Rancangan Penelitian Subjek Penelitian.
Untuk lebih memfokuskan penelitian tindakan kelas ini sasaran utamnya adalah seluruh Peserta Didik kelas III yang berjumlah 23 orang yang mempunyai kemapuan yang berfariasai. Variabel penelitiannya: Variabel input, Variabel Proses danVariabel Output. Prosedur peneltiaannya dilakukan beberapa tahapan Tahap Pelaksanaan TindakanTahap ini peneliti melaksanakan kegiatan sesuai dengan tahapan sebagai berikut; Observasi awal, Siklus I, dan Siklus II.

Teknik Pengumpulan Data melalui Observasi, Hasil belajar Peserta Didik danWawancara. Instrumen penelitian mengacu pada Pedoman observasi, Pedoman wawancara dan Tes Hasil BelajarTeknik Analisis data pada penelitian diolah secara kualitatif dengan menitik beratkan pada permasalahan guru dalam meningkatkan motivasi belajar peserta didik tentang proses terbentuknya hujan melalui penggunaan media berbasis ICT di kelas III SD Laboratorium UNG Kota Gorontalo.

\section{HASIL DAN PEMBAHASAN}

Dari hasil observasi awal ini jika di lihat hasil yang diperoleh Peserta Didik nampak jelas bahwa dari 23 
Peserta Didik yang duduk dikelas III SD Laboratorium UNG Kota

GorontaloNampak masih mendominasi peserta didik yang belum tuntas hal ini setelah dianalisis ternyata penyebabnya adalah peserta didik kurang termotivasi dalam proses pembelajaran hal ini nampak siswa jenuh dalam menerima pembelajaran yang disejikan oleh guru sehingga berdampak pada ketuntasan hasil belajar yaitu: 14 peserta didik atau 61 $\%$ belum tuntas hasil belajarnya, Sedangkan peserta didik yang telah mencapai ketuntasan hasil belajar nampak 9 orang peserta didik dengan persentase $39 \%$. Dari hasil observasi awal ini peneliti dan guru menganalisis dan mengambil kesimpulan bahwa untuk meningkatkan motivasi belajar peserta didik khusunya tentang proses terbentuknya hujandengan pemanfaatan media berbasis ICT

Hasil Pembahasan Tindakan dengan menggunakan media berbasis ICT

Setelah diadakannya kegiatan pembelajaran pada siklus I dengan menggunakan media pembelajaran berbasis ICT nampak hasil capaian yang diperoleh siswa telah mendominasi dengan peningkatan hasil belajar dari 23 jumlah peserta didik keseluruhan terdapat 21 orang siswa atau $92 \%$ yang telah mencapai ketuntasan belajar. serta siswa yang belum berhasil Nampak 2 orang atau 8 $\%$. Ini membuktikan bahwa penggunaan media pembelajaran berbasis ICT dapat menarik minat belajar peserta didik dengan meningkatnya hasil belajar dimana pada observasi awal guru hanya menggunakan metode convensional dengan tidak memanfaatkan media pembelajaran ketentusan belajar cenderung minim dimana ketuntasan belajar hanya mencapai $39 \%$ setelah diadakan penelitian dengan menggunakan media berbasis ict telah terjadi peningkatan hasil belajar sebesar $53 \%$.

Pelaksanaan penelitian tindakan kelas pada pembelajaran IPA di kelas III SD Laboratorium UNG Kota Gorontalo, melalui penggunaan mediapembelajaran berbasis ICT untuk meningkatkan motivasi belajar peserta didikdalam memahami konsep terbentuknya hujan. Telah menunjukkan peningkatan hasil belajar peserta didik hal ini sesuai denganhasil obesrvasi awal dimana ketuntasan belajar hanya mencapai $26 \%$ hal ini menjadi dasar utama.

Tabel 1 Analisis hasil belajar peserta didik dengan menggunakan 


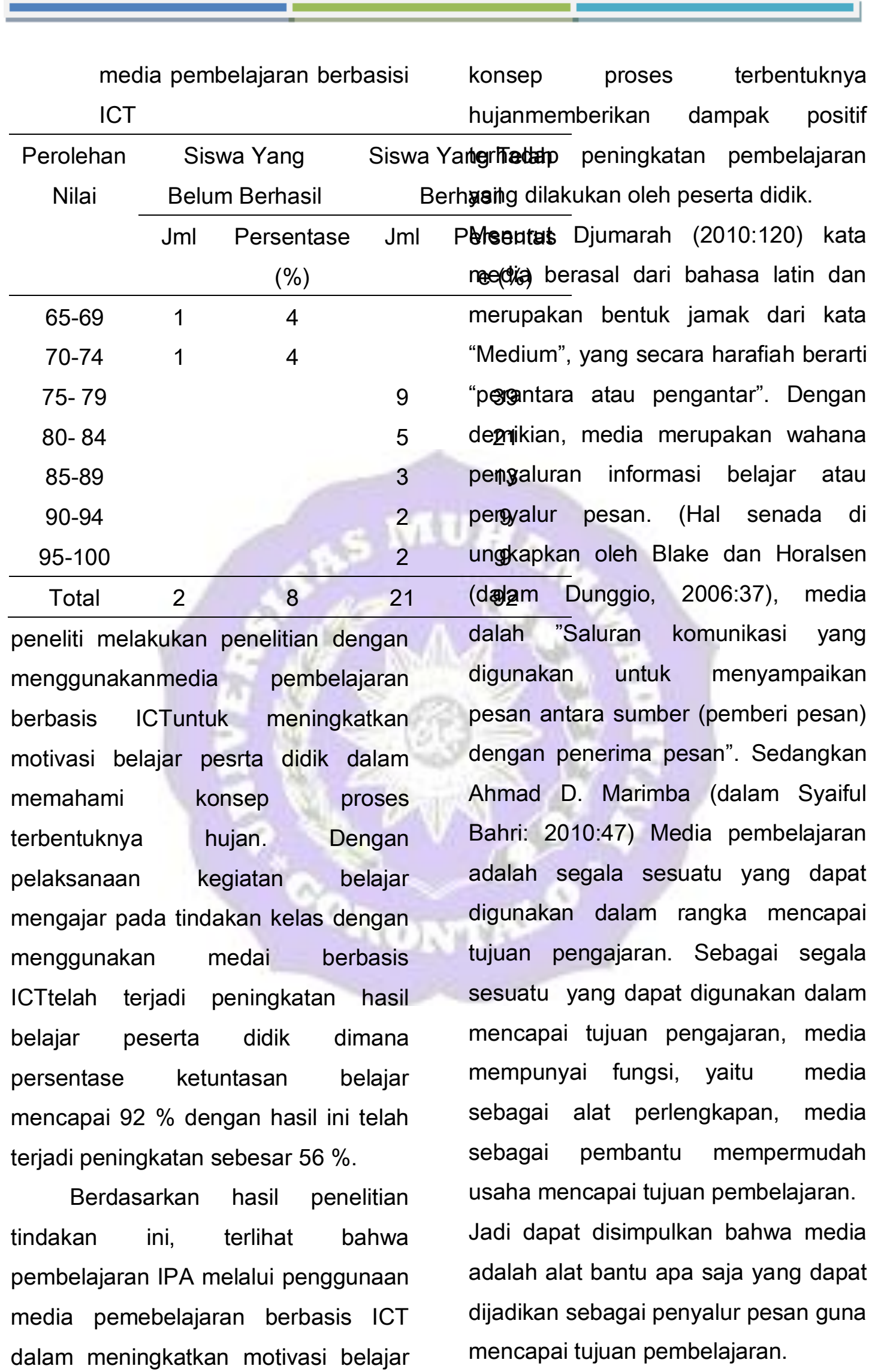

peserta didik dalam memahami 
Pengertian Pembelajaran Berbasis ICT (Information

Communication

Technology)

Pembelajaran berbasis ICT adalah pembelajaran yang berasaskan konsep pembelajaran komputer dan multimedia. Pendidikan bebasis ICT (Information

Communication

Technology) saat ini sudah berkembang pesat di berbagai daerah. Kebutuhan akan berbagai media interaktf semakin dirasakan, mengingat kondisi perkembangan teknologi informasi semakin berkembang pesat. Dalam dunia pendidikan misalnya, siswa mulai prasekolah, SD, SMP, SMA dan SMK dituntut mengenal ICT sejak dini. Untuk mewujudkan sekolah dengan berbasis ICT tentunya diperlukan sarana prasarana yang menunjang. Tanpa sarana dan prasarana yang baik maka pembelajaran tidak akan sulit berjalan dengan sempurna. Sarana prasarana sekolah berbasis ICT adalah seperti Lab komputer, LCD, dan koneksi internet.

Dengan demikian jelas bahwa kebutuhan bahan pembelajaran berbasis ICT sebagai alat untuk membantu siswa menguasai ICT dan materi pelajaran umum lainnya dengan lebih cepat, menyenangkan dan meningkatkan motivasi belajar, menjadi kebutuhan yang mendesak untuk

tercapainya

kualitas

pembelajaran yang diharapkan.

Selain sebagai sarana untuk meningkatkan motivasi belajar siswa, pembelajaran berbasis ICT juga dapat mempermudah guru dalam menyampaikan materi pembelajaran, membiasakan guru untuk menyesuaikan diri dengan perkembangan jaman yang semakin pesat saat ini.Sudah saatnya guru sedikit demi sedikit membiasakan diri mengajar menggunakan media berbasis ICT, tidak hanya mengandalkan buku yang sudah berbagai generasi redaksinya hanya itu-itu saja sehingga sudah sangat hapal diluar kepala.

Iklim kognitif yang dicapai dari kelas berbasis ICT adalah pemahaman terhadap materi karena peserta didik diberikan kesempatan bereksplorasi dengan ICT untuk memecahkan masalah baik secara sintesis maupun analisis.Iklim afektif yang dicapai dari kelas berbasis ICT adalah akomodasi peserta didik lambat dan cepat secara adil. Peserta didik yang lambat tidak akan menjadi bahan olok-olokan temannya, karena keterlambatannya, karena ICT memiliki kesabaran dalam menerima pengulangan-pengulangan sesuai kehendak pengguna (user). Begitu pun peserta didik cepat, tidak akan merasa 
kurang, karena ICT mampu melayani semua rasa ingin tahunya dengan kecepatan sesuai permintaan pengguna (user). Adapun iklim skill adalah yang paling dominan tercapai.Penggunaan ICT menciptakan skill menulis, berkomunikasi, dan mengakses pengetahuan dengan cepat, mudah, dan tepat.

\section{Upaya Guru dalam meningkatkan} Motivasi Belajar melaui pemanfaatan ICT

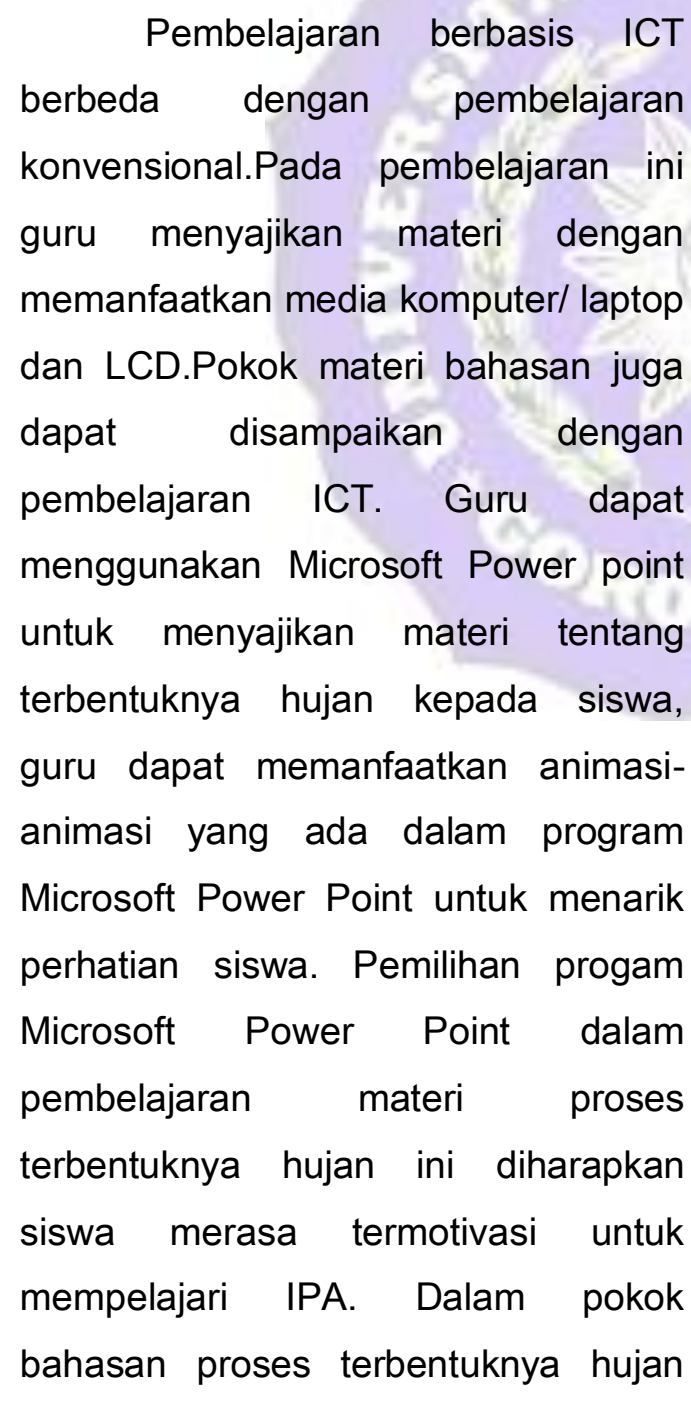

guru dapat memanfaatkan animasianimasi yang ada dalam program Microsoft Power Point untuk menampilkan video. Dengan demikian siswa lebih paham mengenai proses pembentukan hujan secara visual. Dalam menerapkan program Microsoft Power Point ini guru juga dapat menyisipkan audio untuk memperjelas konsep dari materi yang dipelajari, sehingga siswa tidak cepat bosan. Dengan Media Power point guru dapat menyampaikan materi pelajaran menjadi lebih menarik, sehingga siswa lebih paham dan menguasai materi. Selain itu, siswa cenderung tertarik untuk mengikuti proses pembelajaran yang ada dikelas. Menurut Budi Murtiyasa (2008:4) mengenai pemanfaatan teknologi informasi dan komunikasi untuk meningkatkan kualitas pembelajaran IPA menyebutkan kekuatan TIK (power of ICT) telah mendorong para insan pendidikan untuk memanfaatkannya dalam bidang pendidikan.Kekuatan TIK telah mendorong terjadinya perubahan dalam kurikulum, yang meliputi perubahan tujuan dan isi, aktivitas belajar, latihan dan penilaian, hasil akhir belajar, serta nilai tambah yang positif.

Media power point yang menyajikan suatu gambar, animasi, 
atau video yang menampilkan sikap belajar siswa yang baik dalam proses belajar secara tidak langsung akan merangsang perasaan siswa untuk lebih paham bagaimana proses belajar yang baik, baik dalam dalam sikap, tindakan ,dan interaksi dalam proses pembelajaran.

Media pembelajaran baik berupa gambar, tulisan, video, email merupakan suatu perantara yang dapat merangsang pikiran, perasaan, perhatian, minat, dan dapat membawa perubahan yang signifikan dalam hasil akhir belajar, serta nilai tambah yang positif. Dengan kata lain, media pembelajaran berbasis ICT secara tidak langsung dapat meningkatkan motivasi belajar siswa. Keberhasilan proses belajar mengajar dapat dilihat dari prestasi belajar siswa. Banyak faktor yang mempengaruhi keberhasilan siswa antara lain sikap belajar siswa, motivasi belajar, media pembelajaran yang digunakan oleh guru. Dengan demikina dapat disimpulkan bahwa dengan menggunakan media pembelajaran Berbasis ICT dalam proses belajar dapat meningkatkan motivasi belajar peserta didik yang berimbas pada peningktan hasil belajar dengan penggunaan waktu dan biaya yang relatif kecil.

\section{PENUTUP}

\section{Simpulan}

Berdasarkan hasil penelitian tindakan dan pembahasan disimpulkan bahwa motivasi belajar peserta didik kelas III SD Laboratorium UNG Kota Gorontalo tentang pemahaman konsep proses terbentuknya hujan dapat ditingkatkan melaui pemanfaatan media pembelajaran berbasis ICT.

\section{Saran}

Untuk meningkatkan motivasi belajar peserta didik khusunya dalam menamkan konsep proses terbentuknya hujan disarankan agar kiranya guru menggunakan media pembelajaran berbasisi ICT.

\section{DAFTAR PUSTAKA}

Aqib , Zainal. 2013. Model-Model, Media dan Strategi pembelajaran Konsektual (Innovatif). Bandung: Yrama Widya.

Ashar, Arsyad. 2006. Media pembelajaran. Jakarta : PT Raja Grafindo Persada

Aunurrahman.2010. Belajar dan Pembelajaran.Bandung:

Alfabeta.

Budi, Murtiyasa. 2008. Pemanfaatan Teknologi Informasi dan Komunikasi Untuk Meningkatkan Kualitas Pembelajaran.Jakarta : Gaung Persada Press. 
Dimyanti, 2010 Belajar dan

Pembelajaran. Jakarta: Rineka Cipta

Djamarah,dkk. 2010 Strategi Belajar Mengajar. Jakarta: Rineka Cipta.

Rositawaty S, 2008. Senang Belajar IImu IImu Pegetahuan Alam 3:

Untuk Kelas III Sekolah Dasar/Madrasah Ibtidaiyah. Jakarta: Pusat Perbukuan Departemen Pendidikan Nasional

Rosdiana, Penggunaan media pembelajaran berbasis ICT dan pengaruhnya terhadap tingkat kelulusan Ujian Nasional siswa pada sekolah menengah Di Kota Palopo, Jurnal Pendidikan matematika dan IImu pengetahuan alam. Vol 4 No. 1
Hal.73-88 maret 2016. ISSN (P):2527-3744).

Setyosari,dkk. 2009. Media pembelajaran. Malang: Elang Emas

Slameto. 2010. Belajar \& Faktor-Faktor Yang Mempengaruhinya. Jakarta: Rineka Cipta 